PROCEEDINGS OF THE UNITED STATES NATIONAL MUSEUM

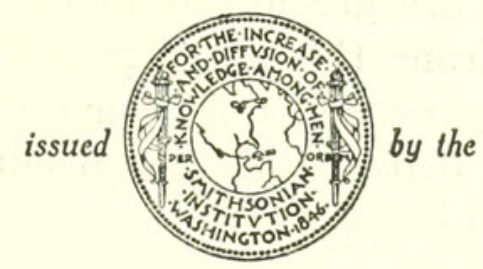

SMITHSONIAN INSTITUTION

U. S. NATIONAL MUSEUM

\begin{tabular}{lll}
\hline \hline Vol. 108 & Washington : 1958 & No. 3403 \\
\hline
\end{tabular}

\title{
RHIZOCEPHALA OF THE FAMILY PELTOGASTRIDAE PARA- SITIC ON WEST INDIAN SPECIES OF GALATHEIDAE
}

\section{By Edward G. Reinhard ${ }^{1}$}

Of the 12 genera of Rhizocephala that make up the family Peltogastridae as currently understood, only Galatheascus and Tortugaster contain species that parasitize anomuran Crustacea of the family Galatheidae. Members of the other genera occur on Paguridae.

In a collection of parasitized galatheids belonging to the Museum of Comparative Zoology (MCZ), Harvard University, that the author, through the courtesy of Dr. Elisabeth Deichmann, had the privilege of studying, some remarkable new representatives of Peltogastridae were encountered. The specimens, obtained off the north coast of Cuba by the Atlantis expeditions to the West Indies in 1938 and 1939, comprise two new species of a new genus that are described in this paper. The Atlantis material also includes Galatheascus minutus Boschma, hitherto unreported from American waters, and Tortugaster fistulatus Reinhard.

An inspection of some of the Galatheidae in the U. S. National Museum brought to light additional examples of one of the new species and of Galatheascus minutus. Moreover, two parasitized specimens

\footnotetext{
${ }^{1}$ A posthumous paper. At the time of his death, Jan. 29, 1958, Dr. Reinhard was with the Department of Biology, The Catholic University of America, Washington, D. C. 
of Munida irrasa A. Milne Edwards from North Carolina and Florida, which had been collected by the U. S. Fish Commission many years ago, also had peltogastrids present that proved to be new. Descriptions of this new genus and new species also are given here.

The two new genera are gregarious in their habit of growth, but they differ markedly from the other gregarious forms in external appearance and in various aspects of their internal anatomy. One of their most distinctive features is the peculiar orientation of the mesentery in relation to the stalk.

\section{Family Peltogastridae}

\section{Cyphosaccus, new genus}

Genotype: Cyphosaccus chacei, new species.

Diagnosis: Gregarious; body elongate, V- or U-shaped; stalk on the left side. Mantle aperture a blind canal which eventually opens to form a birth pore. Testes saccular, small, situated near posterior end. Vasa deferentia directed posteriorly. Colleteric glands in the vicinity of the stalk. On Galatheidae.

When the animal is viewed with the anterior arm to the left and directed upward, the side facing the observer is the mesenterial or dorsal surface. The curvature of the sac is therefore in a lateral direction, with the stalk originating on the left side.

\section{Cyphosaccus chacei, new species}

Figure 1; Plate 1, figure 1

Syntypes: Off Cayo Coco, Cuba, Atlantis Station 3397, lat. $22^{\circ} 34^{\prime} 30^{\prime \prime}$ N., long. $78^{\circ} 16^{\prime}$ W., 180 fathoms, Apr. 28 , 1939; 18 specimens on one Munida irrasa A. Milne Edwards. Harvard-Havana Expedition, Atlantis. MCZ 11431.

Additional specimens: Off Cayo Coco, Cuba, Atlantis Station 3399 , lat. $22^{\circ} 35^{\prime}$ N., long. $78^{\circ} 2^{\prime}$ W., 180 fathoms, Apr. 28, 1939; 10 specimens on one Munida irrasa A. Milne Edwards. HarvardHavana Expedition, Atlantis. MCZ 11432.

Off Havana, Cuba, Albatross Station 2337, lat. $23^{\circ} 10^{\prime} 38^{\prime \prime}$ N., long. $82^{\circ} 20^{\prime} 21^{\prime \prime}$ W., 199 fathoms, Jan. 19, 1885, 15 specimens on one Munida irrasa A. Milne Edwards. Albatross coll. USNM 100943.

Off Pelican Island, Barbados, Station 7, 80 fathoms, Mar. 16, 1918; 1 specimen on Munida irrasa A. Milne Edwards. Barbados-Antigua Expedition. USNM 57962.

Diagnosis: Body slender and V-shaped, with the stalk at the vertex of the angle. Length of anterior arm equal or nearly equal to 

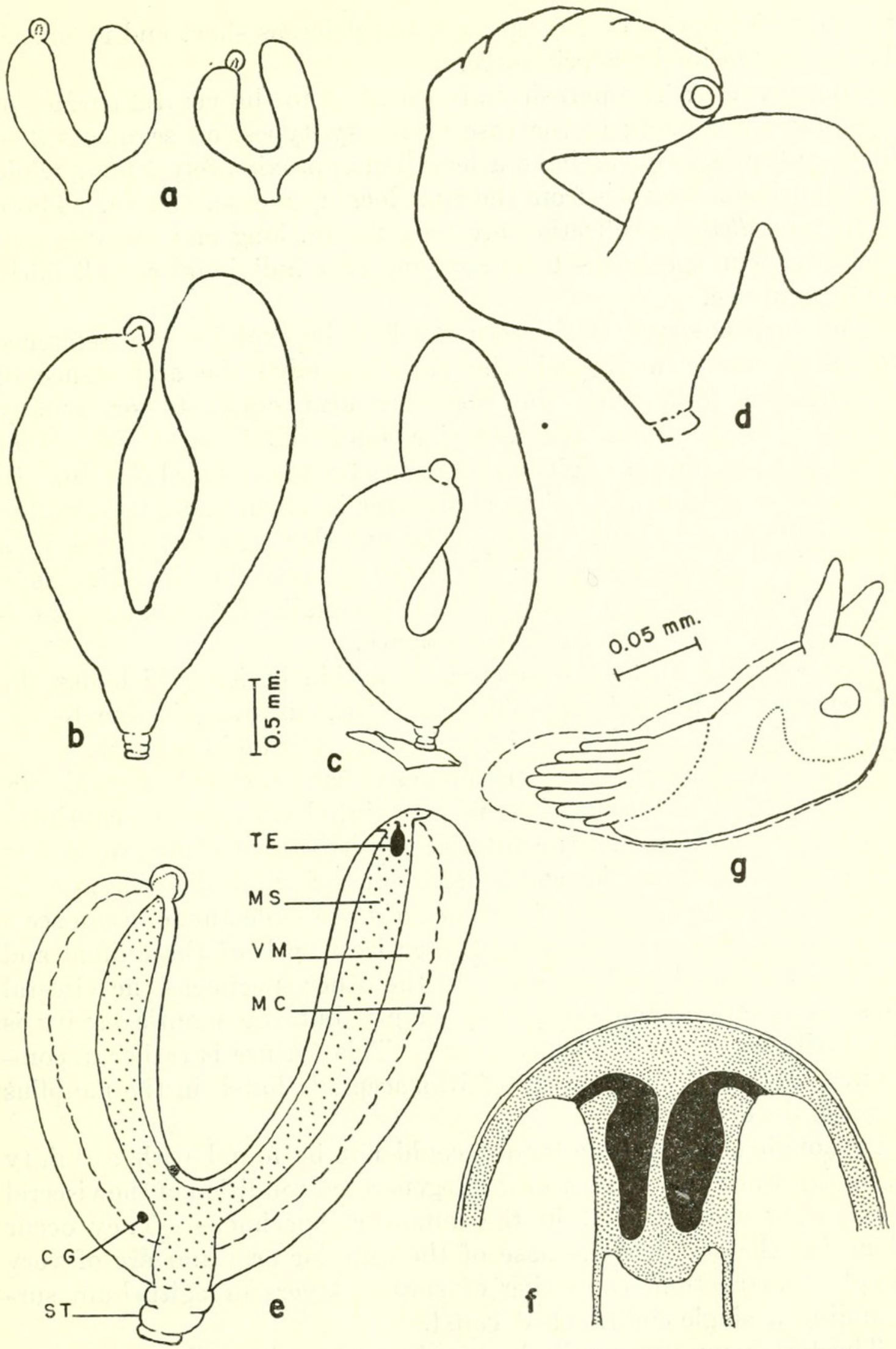

Figure 1.-Cyphosaccus chacei, new species: a, Young specimens (USNM 100943); b, $c$, two of the syntype specimens (MCZ 11431); $d$, older specimen (USNM 57962); $e$, diagram of internal anatomy; $f$, diagram of testes and vasa deferentia; $g$, cypris larva from mantle cavity of syntypes. The scale appearing alongside $b$ refers to $a-d$, which are drawn to the same magnification. Abbreviations: $c g$, colleteric gland; $m c$, mantle cavity; $m s$, mesentery; st, stalk; te, testis; $v m$, visceral mass. 
the posterior one. Testes separate, vas deferens short and recurved. Larvae hatch in the cypris stage.

Description: The parasites are attached to the ventral surface of the host's abdomen; in the case of the syntypes, on segments 3-6. The snytype specimens have a length of approximately $5 \mathrm{~mm}$., while the additional examples from the same locality measure $6 \mathrm{~mm}$. Those from the Albatross collection are only $2 \mathrm{~mm}$. long and are very immature. The specimens from any one host individual are all fairly uniform in size.

The curious shape of the sacs can best be explained by reference to the figures. In general, the parasites have the appearance of a 2-pronged fork, with the posterior arm equal to or usually a little longer than the anterior one. Each arm is rather slender at its point of origin and becomes broader toward the tip. In the mature specimens the lesser diameter is 0.5 to $0.75 \mathrm{~mm}$. and the greater diameter about $1 \mathrm{~mm}$. The anterior arm terminates in a nipple-like prominence, covered by a bulbous sheath which is a continuation of the external cuticle. The stalk of the mature specimens is marked by three circular grooves.

The external surface is covered by a thin cuticle which has the appearance of being finely striated. This, however, is due to the innumerable muscle fibers, chiefly circular, that lie beneath it.

The rather narrow mesentery proceeds from the stalk towards the concave surface of the sac where it passes into both arms and continues to their extremities. At the anterior end its termination is somewhat acute but at the posterior end it flares out to form a thin plate.

In the immature animals from the Albatross collection one can see a compact ovarian mass running the entire length of the animal and filling up the cavity of the sac. In the other specimens the visceral mass is collapsed and completely empty but the mantle cavity is filled with larvae in the cypris stage. This feature is rather uncommon, since the great majority of Rhizocephala hatch in the nauplius stage of development.

Although the colleteric glands could not be found with certainty in the large animals because of the degenerated condition of the visceral mass, they were evident in the immature specimens. They occur alongside the stalk at the base of the anterior arm and are of very simple construction, consisting of several layers of epithelium surrounding a single unbranched canal.

The testes are two small elongated pouches situated near the tip of the posterior arm with their blind ends directed towards the stalk. The outer wall of the organ is made up of a well-defined structureless membrane. Each gives rise to a short vas deferens that soon reverses 

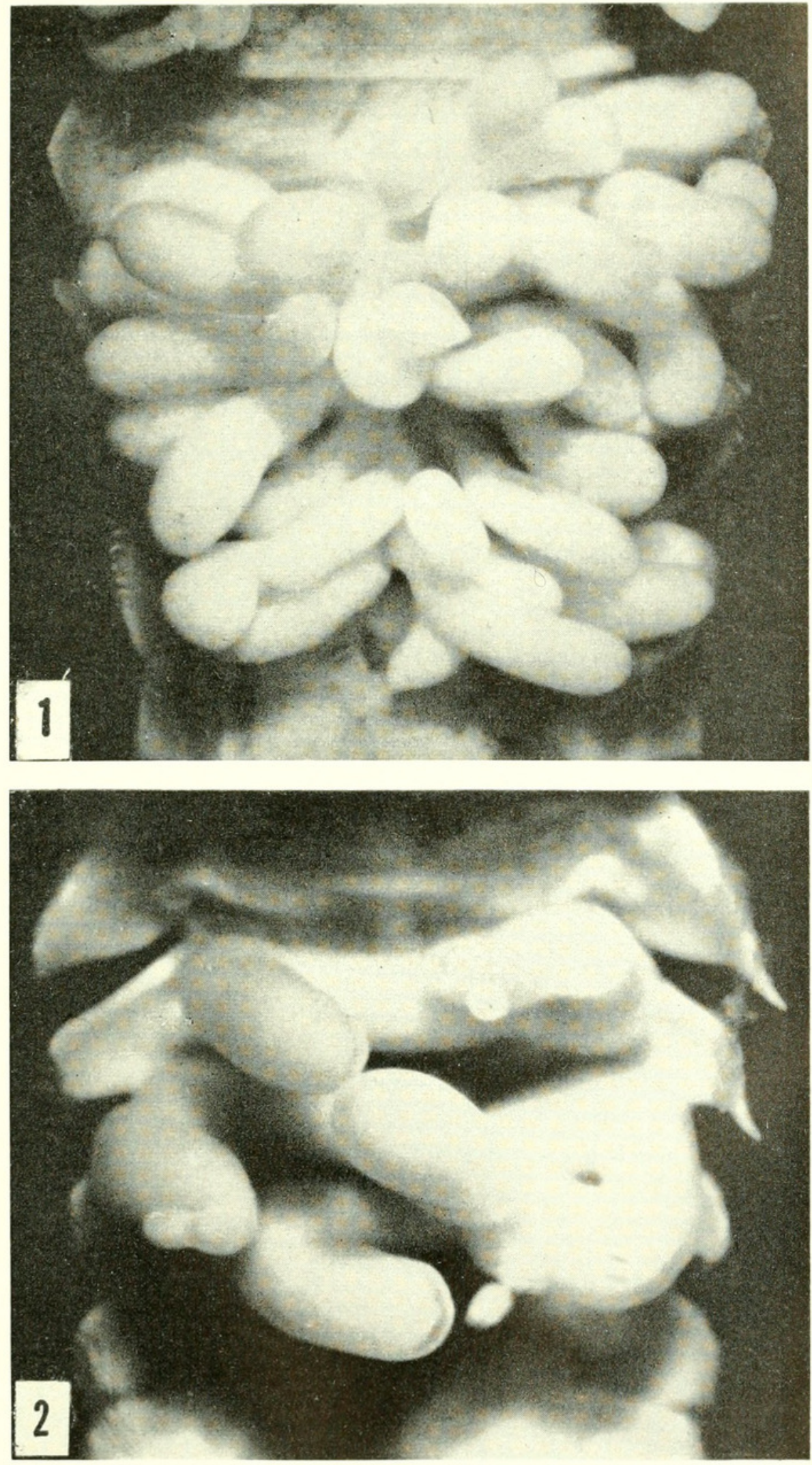

1. Cyphosaccus chacei, new species; 15 specimens attached to abdomen of .Munida irrasa. 2, Cyphosaccus cornutus, new species; three specimens attached to abdomen of Munidopsis erinacea. (Photographs by Henry F. Mengoli.) 

its course to open alongside the testes at the junction of the mesentery with the mantle.

The single specimen from the Barbados (fig. 1, $d$ ) was not sectioned. It appears to be an animal that is undergoing degeneration after the release of its brood. The mantle cavity is empty and the anterior end of the sac has a conspicuous round orifice, presumably the birth pore. The host also bears the scar of a companion parasite no longer present.

Remarks: Dr. Fenner A. Chace, Jr., curator of marine invertebrates, U. S. National Museum, for whom this species is named, recorded the presence of abdominal parasites on three examples of Munida irrasa A. Milne Edwards obtained by the Atlantis off Cayo Coco, Cuba (Chace, 1942, p. 46). Two of these were loaned to the author through the courtesy of the Museum of Comparative Zoology. They provided part of the material described here.

\section{Cyphosaccus cornutus, new species}

Figure 2; Plate 1, Figure 2

Syntypes: Off Playa Baracoa, Havana, Cuba, Atlantis Station 3305 , lat. $23^{\circ} 05^{\prime} 30^{\prime \prime}$ N., long. $82^{\circ} 35^{\prime}$ W., 330 fathoms, Mar. 23, 1939, three specimens on one Munidopsis erinacea (A. Milne Edwards), Harvard-Havana Expedition, Atlantis. MCZ 11721.

Diagnosis: Body broadly U-shaped, comparatively stout, uniform in thickness, with the stalk in the midregion. Testes fused.

Description: The parasites are attached to the sternites of the third and fourth abdominal segments. Two are oriented with the anterior arm towards the left side of the host; the other is turned in the opposite direction. All three are of approximately the same size, $8 \mathrm{~mm}$. in length and about $1 \mathrm{~mm}$. in thickness.

The shape of the sac resembles an ox-bow, although the anterior arm is misshapen. The tip of this arm bears a nozzle-like prominence enclosing a blind canal. The smooth external surface of the sac is covered with a thin cuticle through which an underlying meshwork of delicate longitudinal and circular muscle fibers belonging to the mantle can be seen. The longitudinal fibers are more widely spaced than the circular ones.

When the animal is examined with the anterior arm to the observer's left, as in the drawings, the mesenterial surface lies uppermost. The mesentery, which extends along the entire length of the sac, supports a well-developed visceral mass. In the animals that were sectioned, segmenting eggs are also present in the mantle cavity. Whether they hatch as nauplii or as cypris larvae is not known. 
The testes occur near the posterior end of the mesentery. These elongated sacs are fused for approximately one-third of their length in one specimen, and completely fused in the other. Each gives rise to a vas deferens shaped like an inverted $\mathrm{J}$, which runs in a posterior

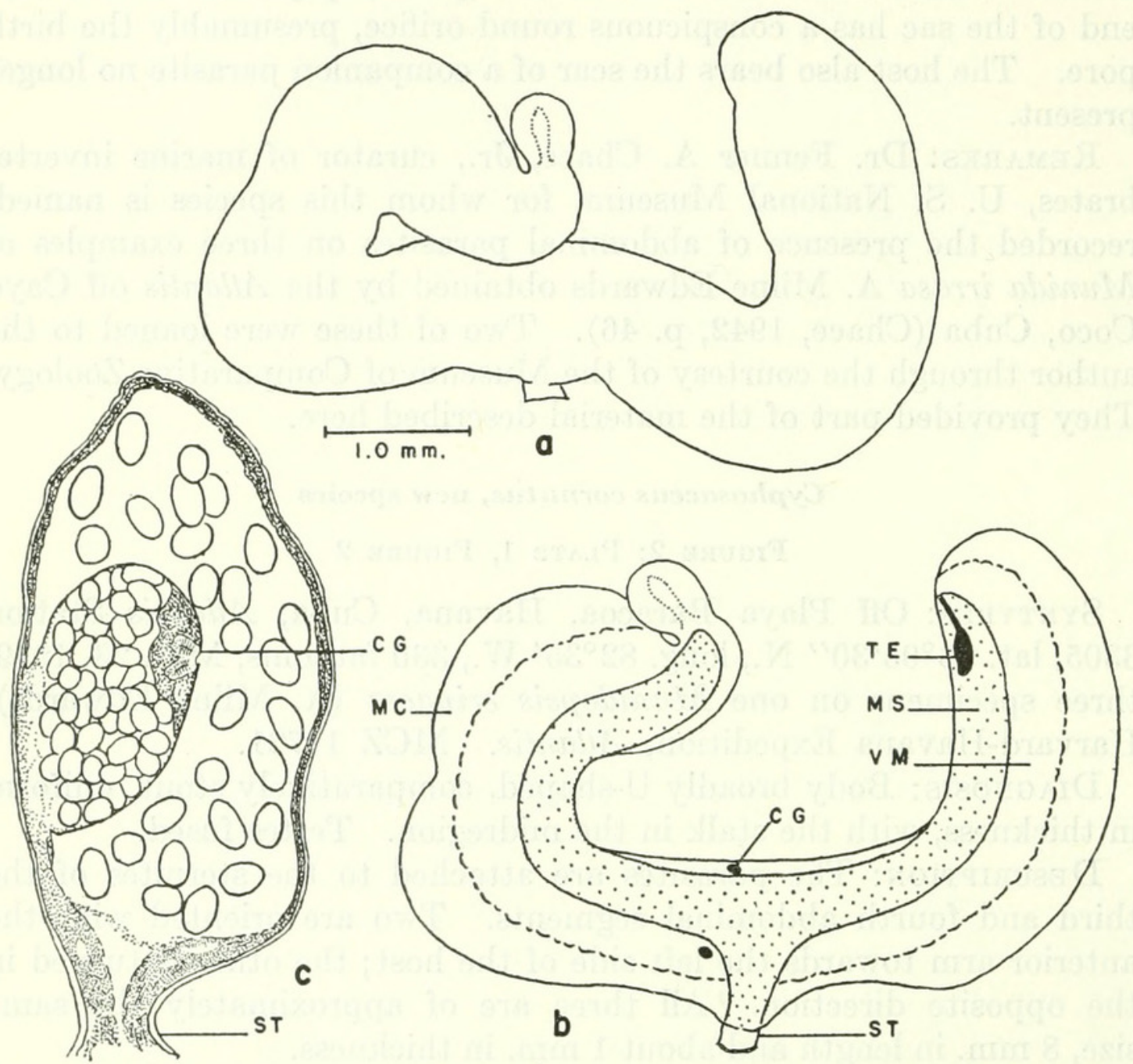

Figure 2.-Cyphosaccus cornutus, new species: $a$, Syntype, external appearance (MCZ $11721) ; b$, diagram of internal anatomy; $c$, section through region of stalk. The scale refers to $a$ and $b$. Abbreviations as in figure 1 .

direction, then curves in the opposite direction shortly before it terminates. The vasa deferentia are about as long as the testes.

The colleteric glands are located in the region of the stalk. They are of simple design, with no more than two or three narrow channels leading to the opening into the mantle cavity.

REMARKS: Chace (1942, p. 90) mentioned the presence of "abdominal parasites" on a female of Munidopsis erinacea (A. Milne Edwards) from Playa Baracoa, Cuba. This is the parasitized specimen that provided the material for the present study. 


\section{Boschmaia, new genus}

Genotype: Boschmaia munidicola, new species.

Diagnosis: Gregarious; body elongate, bifurcate, with arms of unequal length. Mantle aperture covered. Stalk on right side; testes adjacent to stalk. On Galatheidae.

The orientation of the mesentery with respect to the stalk is a distinguishing feature of this genus. In the previously known members of the family Peltogastridae the stalk arises from the dorsal or mesenterial surface, but in Cyphosaccus and Boschmaia it is placed in a lateral position. Whereas in Cyphosaccus the mesentery lies uppermost when the animal is viewed in an upright position with the anterior arm to the observer's left, in Boschmaia the opposite is true. Here the mesentery lies on the far side of the animal when the sac is viewed in the same manner as above. Since the mesentery in Rhizocephala marks the dorsal surface of the animal, the stalk in this genus arises on the right side.

The generic name Boschmaia is given in honor of Prof. H. Boschma, director of the Rijksmuseum van Natuurlijke Historie, Leiden, Holland, the author of more than 80 papers dealing with the Rhizocephala and the foremost authority on this group of animals.

\section{Boschmaia munidicola, new species}

Figure 3

Diagnosis: Anterior arm much longer than posterior one. Testes minute, vasa deferentia long and straight; colleteric glands near anterior end.

Syntypes: Off Cape Lookout, N. C., Fish Hawk Station 7302, U. S. Fish Commission, 71/2 fathoms, July 24, 1902, 9 specimens on one Munida irrasa A. Milne Edwards. USNM 100945.

Additional specimens: Off Key West, Fla., Fish Hawk Station 7279 , U. S. Fish Commission, lat. $24^{\circ} 21^{\prime} 55^{\prime \prime}$ N., long. $81^{\circ} 58^{\prime} 25^{\prime \prime}$ W., 98 fathoms, Feb. 14, 1902, 14 specimens on one Munida irrasa A. Milne Edwards. USNM 100946.

Description: The parasites are attached by means of a short, thin stalk to the third and fourth abdominal segments of the host. They have a somewhat hook-shaped appearance. Each sac is strongly bent, with one arm, which is the anterior part of the animal, nearly twice as long as the other. The basal portion of the sac tapers in the direction of the stalk. At the summit of the anterior arm there is a knob-like prominence formed by the mantle opening. 'The aperture, however, does not communicate with the exterior since it is covered by the external cuticle. 
The syntype specimens are mature animals measuring about $6 \mathrm{~mm}$. in length and 1 to $1.5 \mathrm{~mm}$. in thickness. They contain developing nauplii. Those from Key West are younger specimens, more slender
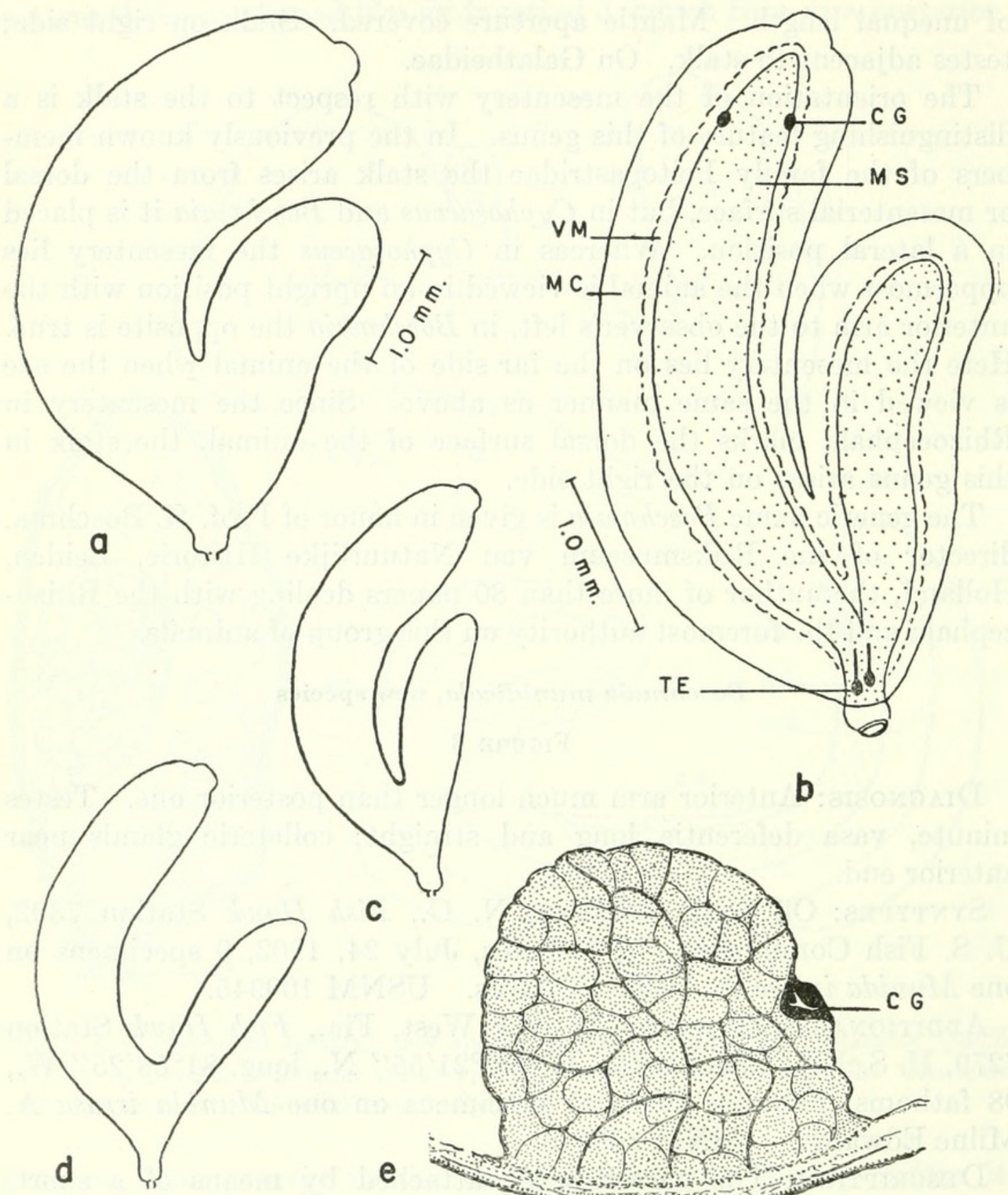

b

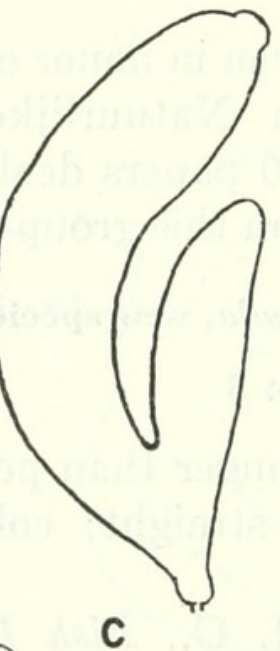

e

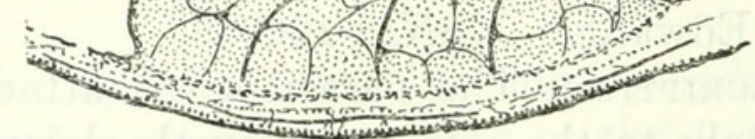

Figure 3.-Boschmaia munidicola, new species: $a$, Syntype, external appearance (USNM 100945); b, diagram of internal anatomy; $c, d$, younger specimens (USNM 100946); $e$, visceral mass and colleteric gland in transverse section. The scale appearing alongside figure $a$ refers to $a, c$ and $d$. Abbreviations as in figure 1 .

in form, without eggs or embryos in the mantle cavity but with a visceral mass that fills up most of the space. They measure about $5 \mathrm{~mm}$. in length and 0.5 to $0.75 \mathrm{~mm}$. in thickness. There is relatively little difference in size between the various sacs found on the same host individual. 
The mantle and visceral mass, in general structure, are like those of Peltogaster paguri and exhibit no unusual features. The mesentery is broad, about equal in width to the visceral mass, and extends from one end of the sac to the other. At the base where the two arms meet there is an extension of the mesentery towards the right to connect with the stalk. The visceral mass accompanies the mesentery to its termination.

The testes are exceedingly small, rounded bodies set close to the stalk. They measure only 35 to 40 microns in diameter. The straight and comparatively long vasa deferentia pursue an upward course away from the stalk along the surface of the basal extension of the visceral mass. Their length is about 250 microns.

The colleteric glands are located near the anterior end of the sac, with the left gland slightly in advance of the right. In a cross section of the animal the gland appears as an elliptical mass comprising a single canal surrounded by several layers of cells. Its depth is 60 to 80 microns and its extent in a dorsoventral direction is about 150 microns.

\section{Genus Tortugaster Reinhard}

\section{Tortugaster fistulatus Reinhard}

Figure $4, e$

Tortugaster fisiulatus Reinhard, 1948, pp. 33-37, fig. 1 (external appearance, internal structures), fig. 2 (transverse section), fig. 3 (vas deferens).

Material examined: South of Cay Sal Bank, north coast of Cuba, Atlantis Station 2987, lat. $23^{\circ} 22^{\prime}$ N., long $79^{\circ} 53^{\prime}$ W., 280-300 fathoms, Mar. 13, 1938; one specimen on Munidopsis spinifer (A. Milne Edwards). Harvard-Havana Expedition. MCZ 11755.

East of St. Augustine, Fla., Atlantis Station 3780, lat. $30^{\circ} 27^{\prime}$ N., long. $79^{\circ} 52^{\prime}$ W., 250-265 fathoms, Feb. 24, 1940; one specimen on Munidopsis bahamensis Benedict. MCZ 11734.

These are new locality and new host records for a species that has previously been known only from the type specimens found on Munidopsis robusta A. Milne Edwards, off Tortugas, Fla. In their attachment and orientation with respect to the host and in their external appearance these examples of $T$. fistulatus agree with the type. The specimen on Munidopsis spinifer measures $6 \mathrm{~mm}$. in length and $3 \mathrm{~mm}$. in width and is a mature animal with eggs present in the mantle cavity. The parasite on Munidopsis bahamensis is also fully developed and differs from the other only in size. Its length is $8 \mathrm{~mm}$. and width $4.5 \mathrm{~mm}$. Because of their poor state of preservation these animals were not sectioned. They are the specimens ("abdominal parasites") mentioned by Chace (1942, pp. 89, 91) in 
his report on the Galatheidae obtained by the Atlantis expeditions to the West Indies.

\section{Genus Galatheascus Boschma}

\section{Galatheascus minutus Boschma}

Figure $4, a-d$

Galatheascus minutus Boschma 1933, pp. 476-478, fig. 1 (external appearance), figs. 2, 3 (transverse sections) ; 1947, pp. 2-4, fig. 1 (attached to host).

Type specimen on Galathea nexa Embleton, from Oban, Scotland.

Material examined: Off Cayo Coco, north coast of Cuba, 180 fathoms, 1939; two specimens on one Munida stimpsoni A. Milne Edwards. Atlantis Coll. MCZ 11344.

Gulf of Mexico, Blake Station 45, lat. $25^{\circ} 33^{\prime}$ N., long $84^{\circ} 21^{\prime}$ W., 101 fathoms, 1877-78; one specimen on Munidopsis barbarae (Boone). Blake Coll. MCZ 11719. (Chace, 1942, p. 81, mentions this specimen. The host is an intersex.)

Off Cape Lookout, N. C., Fish Hawk Station 7302, U. S. Fish Commission, 71/2 fathoms, July 24, 1902; one specimen on Munida irrasa A. Milne Edwards. USNM 100944.

Off Fort Pierce, Fla., Combat Station 235, lat. $27^{\circ} 27^{\prime}$ N., long. $78^{\circ} 58^{\prime}$ W., 180 fathoms, Feb. 2, 1957; one specimen on Munida schroederi Chace. USNM 100947.

All five specimens are oriented with their long axis perpendicular to the main axis of the host and with the anterior end directed towards the right. The site of attachment is on the second or third abdominal segment. The largest parasite, found on Munida schroederi, measures $7 \mathrm{~mm}$. in length, $4 \mathrm{~mm}$. in width, and $3 \mathrm{~mm}$. in thickness; the smallest, found on Munidopsis barbarae, measures 3 by 2 by 1.5 $\mathrm{mm}$. All have developing embryos in the mantle cavity and are therefore mature animals.

The mantle opening in three of the specimens is small, indistinct, and narrow, but in the parasites of Munidopsis barbarae and Munida schroederi it is wider and surrounded by an elevated rim. The short, thin stalk, which is oval in cross section, arises in the median dorsal part of the body. The smooth external cuticle is only about 4 microns thick except where it forms an inconspicuous shield around the base of the stalk.

In order to study the internal cuticle, one of the specimens occurring on $M$. stimpsoni was macerated in $\mathrm{KOH}$. Retinacula were found on the cuticle covering the visceral mass but not on the lining of the mantle. They consist of one to three spindles having a length of 7 to 10 microns and a width of 2 to 3 microns. The retinacula of Galatheascus striatus, which they resemble in all respects except size, are 20 to 25 microns long. 


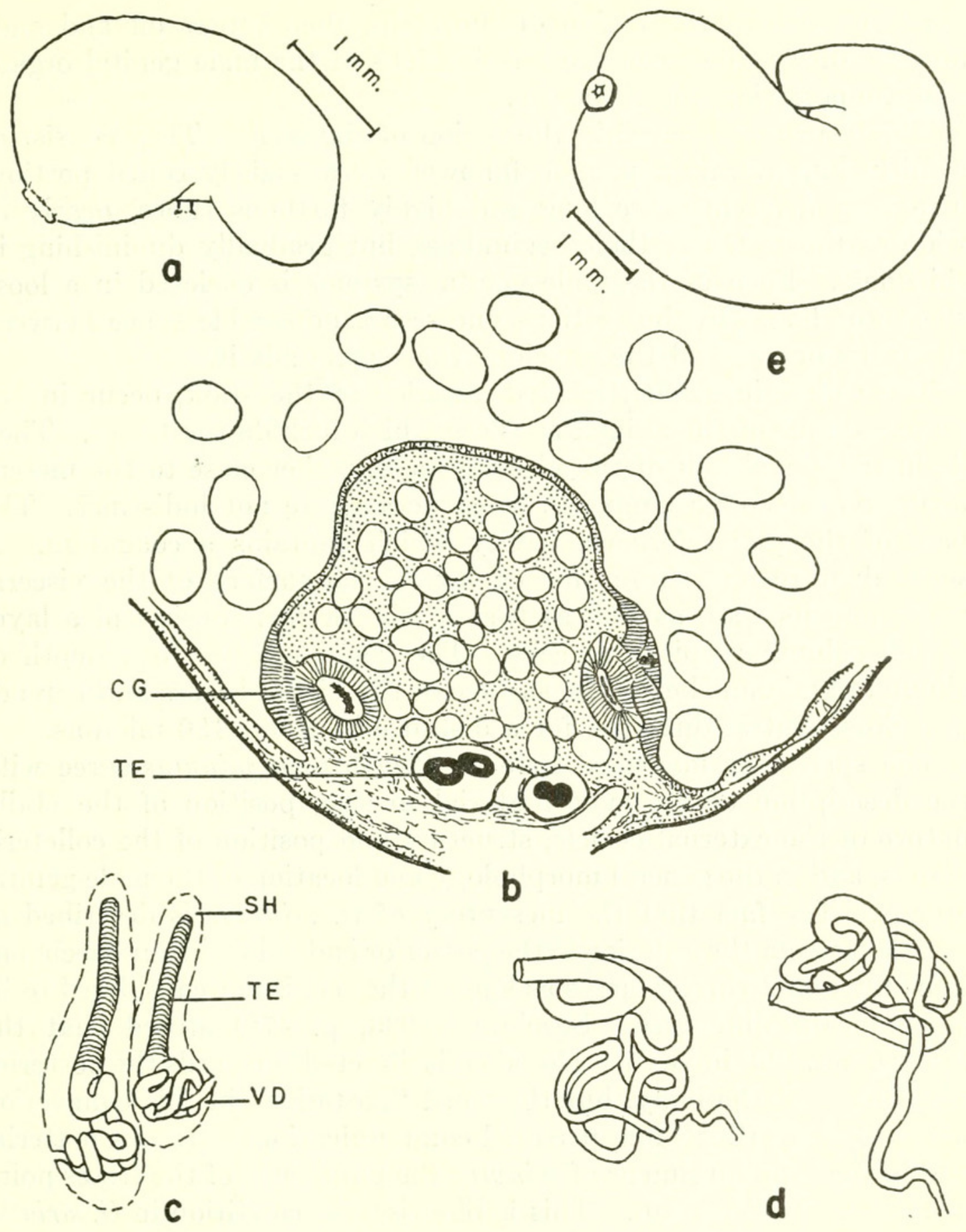

Figure 4.- $a-d$, Galatheascus minutus Boschma: $a$, external appearance of specimen on Munidopsis barbarae; $b$, transverse section of the same specimen; $c$, testes and vasa deferentia of specimen on Munida stimpsoni; $d$, chitinous linings of vasa deferentia revealed by maceration of another specimen on Munida stimpsoni; e, Tortugaster fistulatus Reinhard, external appearance of specimen on Munidopsis spinifer. Abbreviations: sh, sheath; $v d$, vas deferens; others as in figure 1.

Serial sections of the other parasite occurring on $M$. stimpsoni and of the Blake specimen were prepared. No differences were observable in the details of their internal anatomy.

The mesentery begins just behind the mantle opening and gradually increases in width as it passes backwards. It reaches its maxi- 


\section{$2 \mathrm{BHL}$ Biodiversity Heritage Library}

Reinhard, Edward G. 1958. "Rhizocephala of the family Peltogastridae parasitic on West Indian species of Galatheidae." Proceedings of the United States National Museum 108(3403), 295-307. https://doi.org/10.5479/si.00963801.108-3403.295.

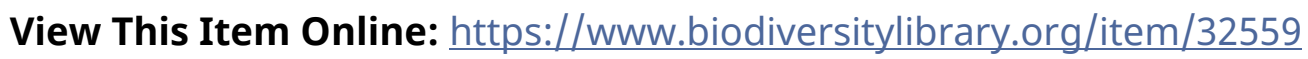

DOI: https://doi.org/10.5479/si.00963801.108-3403.295

Permalink: https://www.biodiversitylibrary.org/partpdf/7092

\section{Holding Institution}

Smithsonian Libraries

\section{Sponsored by}

Smithsonian

\section{Copyright \& Reuse}

Copyright Status: NOT_IN_COPYRIGHT

Rights: https://www.biodiversitylibrary.org/permissions/

This document was created from content at the Biodiversity Heritage Library, the world's largest open access digital library for biodiversity literature and archives. Visit BHL at https://www.biodiversitylibrary.org. 